\title{
Low Leptin Availability as a Risk Factor for Dementia in Chilean Older People
}

\author{
Cecilia Albala ${ }^{a}$ Barbara Angel $^{a}$ Lydia Lera $^{a}$ Hugo Sanchez $^{a}$ \\ Carlos Marquez $^{a}$ Patricio Fuentes ${ }^{b}$ \\ a INTA, University of Chile, and ${ }^{b}$ Department of Neurology, Clinic Hospital, University of \\ Chile, Santiago, Chile
}

Key Words

Obesity $\cdot$ Dementia $\cdot$ Free leptin $\cdot$ Soluble leptin receptor

\begin{abstract}
Objective: The aim was to study the role of leptin in the development of dementia. Methods: Follow-up of the ALEXANDROS cohorts, with baseline measurements in 2000. From 1,136 available subjects free of dementia at baseline, 667 subjects had frozen baseline blood samples for measuring leptin and soluble leptin receptor (sOB-R). The free leptin index (FLI) was calculated as the ratio of leptin to sOB-R. Dementia was defined as an MMSE score <22 and a score $>5$ in the Pfeffer Activities Questionnaire. Results: After 15 years of follow-up, 42 incident cases of dementia were identified. No difference in serum leptin was observed between people with and without dementia, but SOB-R was higher in demented than in nondemented subjects (sOB-R: $44.94 \pm 23.97$ vs. $33.73 \pm 21.13 \mathrm{ng} / \mathrm{ml}$ ). The adjusted risk for dementia increased, the higher the log sOB (hazard ratio $=3.58 ; 95 \%$ CI 1.72-7.45, $p=0.001$ ). Conclusion: Lower availability of free leptin was found in demented than in nondemented people, suggesting a role of leptin in cognition.

\section{Introduction}

As the population in Latin America is aging, dementia is becoming a major public health problem mirroring the rates seen in developed countries. A review of 8 studies in 6 countries [1] found a global prevalence of 7.1\% (95\% CI 6.8-7.4) in people aged 65 years and older, with rates being twice as high in the illiterate versus literate population. Alzheimer's disease (AD) accounts for most cases of dementia. Similar results are published for Argentina, Brazil 
and Venezuela in a review done in developing countries by the world federation research group [2]. In Chile, the reported prevalence of dementia in the SABE study was $8.1 \%$ in the total sample, with higher rates among women (8.9\%) compared to men (6.9\%) and $22.8 \%$ in illiterate women [3]. In a representative sample of older urban Chileans, the rates were $7.3 \%$ in the total sample but $25.5 \%$ among people aged 80 years and older [4].

Several epidemiological longitudinal studies have shown that obesity in midlife is a risk factor for dementia [5, 6]. Obesity may increase the risk of cognitive impairment by actions at both central and peripheral levels. Vascular health and neurodegeneration have been linked to insulin resistance, low-grade inflammation, dyslipidemia and diabetes, especially for its effect on the brain microcirculation. However, new hypotheses have recently arisen, linking adipose tissue to this association [7]. Although the mechanisms are not clearly elucidated, various pathways mediated by the action of adipokines in certain brain regions have been proposed.

Growing evidence on the effect of leptin is emerging. Experimental studies show that leptin modulates structural and functional changes in the hippocampus and improves memory. In leptin-deficient rats, lower brain volume and disruption of hypothalamic pathways have been demonstrated [8]. More importantly, in vitro studies have shown that infusion of leptin reduces $\beta$-amyloid secretion and leptin treatment in leptin-deficient rats reduces levels of $\beta$-amyloid in the brain $[9,10]$. Leptin reduces the activity of $\beta$-secretase and increases the APOE-dependent uptake of $\beta$-amyloid in neurons [11]. Paradoxically, leptin levels are increased in obesity, and in accordance with experimental studies in rats, leptin also increases with aging [12-14].

The actions of leptin are mediated by the leptin receptor (OB-R) belonging to the family of class I cytokine receptors $[15,16]$. There are leptin receptors in hypothalamic neurons and neurons of the cerebral cortex and hippocampus [17]. Furthermore, the presence of a soluble receptor (sOB-R), which represents the main leptin binding activity, has been demonstrated in peripheral blood $[18,19]$ and reflects the density of the membrane OB-R [20].

The maintenance of high levels of adiposity besides high leptin levels suggests an alteration of leptin action in obese older adults. Leptin resistance would be produced by an alteration of transport across the blood-brain barrier or intrinsic resistance of the sensitive neurons of the hypothalamus, hippocampus and other brain regions [21]. Therefore, the determination of leptin resistance is crucial to study the association between leptin and dementia. Leptin resistance has been studied by the free leptin index (FLI) highlighting the importance of leptin availability for leptin action.

In this context, the current study estimated the independent contribution of leptin availability for developing dementia.

\section{Methods}

\section{Subjects}

Follow-up of the subjects recruited for the Santiago de Chile SABE study [22] and the ALEXANDROS study was designed to study the trajectories of disability associated with obesity in older Chileans [23]. As shown in the data flow (fig. 1), at baseline, 2,026 subjects from the SABE and ALEXANDROS cohorts had complete data and 1,903 were free of dementia. As of June 30, 2015, information from 1,588 participants was available, 229 were lost to follow-up and 86 refused participation. From the 1,588 subjects, 452 had deceased. After 7,405.9 person-years of follow-up, a total of 106 dementia cases were identified. Among the 1,136 participants evaluated, 667 subjects had frozen baseline blood samples available for the current analysis, among which 42 incident dementia cases were identified. 
Albala et al.: Low Leptin Availability as a Risk Factor for Dementia in Chilean Older People

Fig. 1. Data flow.

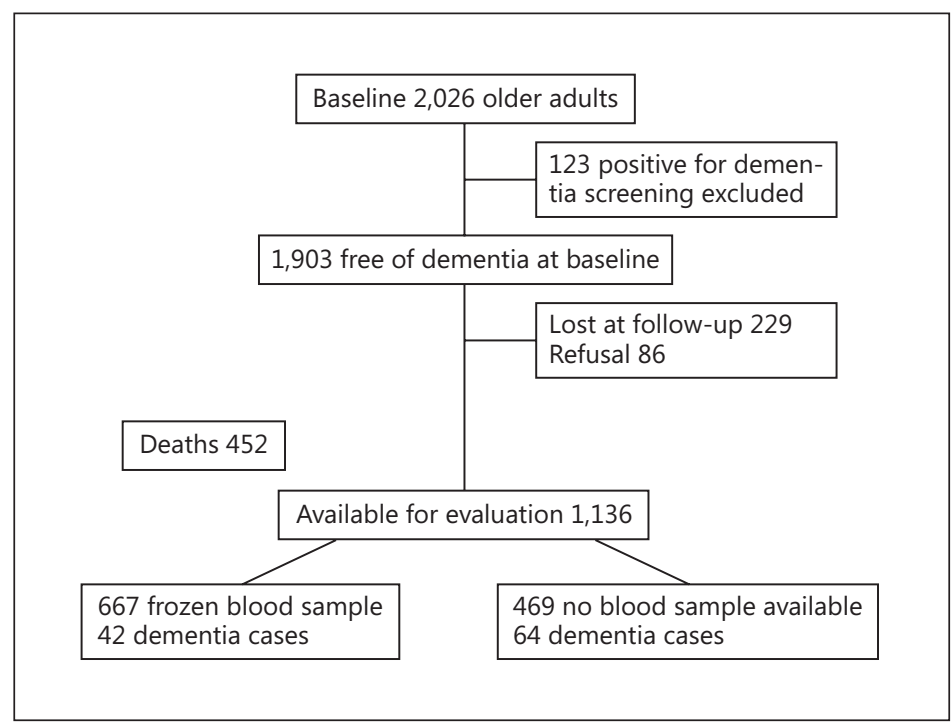

The study protocol was approved by the institutional review board of the Institute of Nutrition and Food Technology of the University of Chile and the Ethics Committee of the Chilean National Council for Science and Technology Research (CONICYT). All the participants provided informed consent for the use of the frozen samples for future research.

\section{Diagnostic Criteria}

Dementia was defined with a screening test validated for Chile consisting of a score $<22$ on the Mini Mental State Examination (MMSE) [24] and a score $>5$ in the Pfeffer Activities Questionnaire [25], a combination that estimates the prevalence, with $94.4 \%$ sensibility (95\% CI 58.9-80.3) and 83.3\% specificity (95\% CI 72.3-90.7) [26]. Depression was assessed with the Geriatric Depression Scale (GDS-15) [27] and defined as having a score $>4$.

\section{Measurements}

In the cohorts studied, all subjects provided blood samples at the first evaluation. These samples were frozen at $-80^{\circ} \mathrm{C}$. The samples were thawed and plasma levels of leptin, adiponectin and soluble leptin receptor (sOB-R) were determined according to the manufacturer's protocol.

Leptin levels were measured using ELISA (ALPCO, Diagnostics, Salem N.H., USA). The limit of detection for leptin was $0.50 \mathrm{ng} / \mathrm{ml}$. The intra-assay coefficient of variation was $4.6 \%$ and the interassay coefficient of variation was $6.0 \%$. sOB-R was measured by ELISA kit (Cusabio, Biotech Co., Ltd., PR China), with a limit of sensitivity of $0.78 \mathrm{pg} / \mathrm{ml}$, an intra-assay coefficient of variation of $<8 \%$ and an interassay coefficient of variation of $<10 \%$. The FLI was defined as the ratio of leptin to sOB-R. Adiponectin levels were measured using a total adiponectin ELISA (ALPCO, Diagnostics). The limit of detection was $0.019 \mathrm{ng} / \mathrm{ml}$. The intra-assay coefficient of variation was $5.4 \%$ and the interassay coefficient of variation was $5.0 \%$.

\section{Statistical Analysis}

Continuous variables were expressed as means \pm SD and 95\% CI. Categorical variables were expressed as medians and percentiles or percentages and $95 \% \mathrm{CI}$. Both the difference between sex and the difference between incident cases of dementia and controls were calculated by two-sample mean-comparison test or Pearson's $\chi^{2}$ test, depending on the type of 
Albala et al.: Low Leptin Availability as a Risk Factor for Dementia in Chilean Older People

Table 1. Baseline characteristics of the subjects by sex

\begin{tabular}{|c|c|c|c|}
\hline & Men $(n=200,30 \%)$ & Women $(n=467,70 \%)$ & Total $(n=667,100 \%)$ \\
\hline Age, years & $65.9 \pm 3.34(65.44-66.37)$ & $66.0 \pm 3.2(65.7-66.3)$ & $66.0 \pm 3.3(65.7-66.2)$ \\
\hline \multicolumn{4}{|l|}{ Years of education } \\
\hline $0-7$ & $58.8(57.2-65.9)$ & $61.7(57.2-66.2)$ & $60.8(57.0-64.6)$ \\
\hline$\geq 8$ & $41.2(34.1-48.3)$ & $38.3(33.8-42.9)$ & $39.2(35.4-43.0)$ \\
\hline Living alone & $9.3(5.6-14.3)$ & $8.4(6.0-11.3)$ & 8.7 (6.4-10.9) \\
\hline \multicolumn{4}{|l|}{ BMI } \\
\hline$<20$ & $2.0(0.55-5.04)$ & $1.29(0.16-2.42)$ & $1.5(0.72-2.7)$ \\
\hline $20-24.9$ & $21.0(15.10-26.90)$ & $16.13(12.7-19.6)$ & $17.6(14.8-20.7)$ \\
\hline $25-29.9$ & $50.5(43.3-57-7)$ & $44.73(40.10-49.36)$ & $46.5(42.6-50.3)$ \\
\hline$\geq 30$ & $26.5(20.13-32.90)$ & $37.85(33.33-42.37)$ & $34.4(30.8-38.2)$ \\
\hline Waist circumference ( $>88 \mathrm{~cm}$ in men, $>102 \mathrm{~cm}$ in women $)^{* * *}$ & $32.2(25.4-38.9)$ & $71.6(67.4-75.8)$ & $59.8(56-63.6)$ \\
\hline Adiponectin, ng/ml*** & $9.14 \pm 3.59(8.59-9.68)$ & $12.91 \pm 5.32(12.39-13.43)$ & $11.80 \pm 2.3(11.61-11.99)$ \\
\hline $\mathrm{sOB}-\mathrm{R}, \mathrm{ng} / \mathrm{ml}^{* * *}$ & $26.86 \pm 15.97(24.72-29.18)$ & $37.55 \pm 22.70(35.57-39.70)$ & $34.43 \pm 21.47(32.80-36.06)$ \\
\hline Leptin, ng/ml & $11.31 \pm 9.04(10.05-12.57)$ & $27.26 \pm 15.58(25.81-28.64)$ & $22.45 \pm 15.73(21.26-23.65)$ \\
\hline Median FLI (25th-75th percentile)*** & $0.56 \pm 0.56(0.49-0.64)$ & $0.99 \pm 0.93(0.91-1.08)$ & $0.87 \pm 0.86(0.80-0.93)$ \\
\hline Diabetes & $17.50(12.5-23.5)$ & $15.91(12.7-19.6)$ & $16.5(13.7-19.4)$ \\
\hline Hypertension & $55.8(48.6-62.9)$ & $42.5(38.0-47.2)$ & $46.5(42.6-50.4)$ \\
\hline Depression & $26.5(20.0-33.8)$ & $31.4(26.9-36.1)$ & $29.6(26.2-33.8)$ \\
\hline
\end{tabular}

Values are means \pm SD with $95 \% \mathrm{CI}$ in parentheses or percentages with $95 \% \mathrm{CI}$ in parentheses, unless indicated otherwise. ${ }^{* * *} \mathrm{p}<0.001$.

variables. Previous log transformation of leptin and sOB-R concentrations, and Cox proportional hazard models were used to analyze the association among studied variables and dementia. All statistical analyses were performed using STATA 14 software (StataCorp. 2015, Stata Statistical Software, release 14, College Station, Tex., USA).

\section{Results}

The baseline characteristics of the 667 subjects studied (70\% women) are displayed in table 1. Mean age was 60 years (SD 3.3 years), $8.7 \%$ of the sample lived alone and $60 \%$ had less than 8 years of education, which was similar in both men and women. A high proportion of the sample was obese, with rates being higher in women [37.9\% (33.33-42.37)] compared to men [26.5\% (20.13-32.90)]. The frequency of hypertension was $46.5 \%$, that of diabetes was $16.5 \%$ and that of depression was $29.6 \%$, similar in both men and women.

Leptin and sOB-R levels were higher in women (leptin $27.26 \pm 15.58 \mathrm{ng} / \mathrm{ml}$; sOB-R 37.55 $\pm 22.7 \mathrm{ng} / \mathrm{ml}$ ) than in men (leptin $11.31 \pm 9.04 \mathrm{ng} / \mathrm{ml} ; \mathrm{sOB}-\mathrm{R} 26.858 \pm 15.87 \mathrm{ng} / \mathrm{ml} ; \mathrm{p}<0.001$ ). FLI and adiponectin were also higher in women than in men $(0.999 \pm 0.925$ vs. $0.564 \pm 0.557$, $\mathrm{p}<0.001$, and $12.91 \pm 5.3$ vs. $29.14 \pm 3.59 \mathrm{ng} / \mathrm{ml}, \mathrm{p}<0.001$ )

As of June 30,2015, the incident cases of dementia were 42 (64.3\% women) out of 667. The mean age of the cases was higher than that of noncases ( $67.4 \pm 0.49$ vs. $65.88 \pm 3.02$ years, $\mathrm{p}<0.01$ ), with a higher proportion having $<8$ years of education among the subjects with dementia versus those without dementia ( 83.3 vs. $59.3 \%, \mathrm{p}=0.02$ ) as shown in table 2 .

Leptin concentration was not different between the groups; however, sOB-R was higher in subjects with dementia compared to those without dementia (44.94 \pm 23.97 vs. $33.73 \pm$ $21.13 \mathrm{ng} / \mathrm{ml}, \mathrm{p}=0.0012$ ) and FLI was lower in demented compared to nondemented subjects $(0.69 \pm 0.86$ vs. $0.88 \pm 0.85, p=0.081)$. No differences between the demented and nondemented group were observed regarding hypertension or diabetes at baseline, although the proportion of depression at baseline was higher among incident cases compared to noncases. Differences in nutritional state were observed mainly in the proportion of people with a BMI $<20$ among the incident cases (table 2).

In table 3, the plasma leptin, sOB-R and FLI concentration by BMI and waist circumference categories are shown. Higher leptin and FLI were observed in obese compared to 
Albala et al.: Low Leptin Availability as a Risk Factor for Dementia in Chilean Older People

Table 2. Baseline characteristics and mean adipokine levels and FLI in incident cases of dementia and subjects without dementia at the end of follow-up

\begin{tabular}{|c|c|c|c|}
\hline & Demented $(n=42)$ & Nondemented $(n=625)$ & $\mathrm{p}$ \\
\hline Age $^{\mathrm{a}}$, years & $67.4 \pm 0.49(65.66-69.09)$ & $65.88 \pm 3.02(65.64-66.11)$ & 0.0037 \\
\hline Gender & & & n.s. \\
\hline Women & $64.3(48.0-78.4)$ & $70.4(66.7-74.1)$ & \\
\hline Men & $35.7(21.6-52.0)$ & $29.6(25.9-33.3)$ & \\
\hline Years of education & & & 0.002 \\
\hline $0-7$ & $83.3(70.9-95.8)$ & $59.3(55.3-63.2)$ & \\
\hline$\geq 8$ & $16.7(4.2-29.1)$ & $40.7(36.8-44.7)$ & \\
\hline Leptin, ng/ml & $22.57 \pm 15.71(21.33-23.80)$ & $20.76 \pm 16.16(15.73-25.80)$ & $0.472^{\mathrm{b}}$ \\
\hline $\mathrm{sOB}-\mathrm{R}, \mathrm{ng} / \mathrm{ml}$ & $44.94 \pm 23.97(37.47-52.41)$ & $33.73 \pm 21.13(32.07-35.39)$ & $0.0012^{\mathrm{b}}$ \\
\hline FLI & & & $0.013^{\mathrm{a}}$ \\
\hline Mean \pm SD & $0.69 \pm 0.86(0.42-0.96)$ & $0.88 \pm 0.85(0.81-0.95)$ & \\
\hline Median (25th-75th percentile) & $0.33(0.17-0.84)$ & $0.63(0.17-0.84)$ & \\
\hline Adiponectin, $\mathrm{ng} / \mathrm{ml}$ & $13.44 \pm 4.91(11.90-14.99)$ & $11.68 \pm 5.163884(11.24-12.12)$ & $0.035^{b}$ \\
\hline BMI & & & 0.012 \\
\hline$<20$ & $7.14(1.49-19.48)$ & $1.12(0.45-2.3)$ & 0.0144 \\
\hline $20-24.9$ & $21.43(10.3-36.8)$ & $17.34(14.4-20.5)$ & 0.64 \\
\hline $25-29.9$ & $35.71(21.55-51.97)$ & $47.1943 .20-51.20)$ & 0.199 \\
\hline$\geq 30$ & $35.71(21.55-51.97)$ & $34.35(30.6-38.2)$ & 0.99 \\
\hline $\begin{array}{l}\text { Waist circumference (>88 cm in men, } \\
>102 \mathrm{~cm} \text { in women })\end{array}$ & $54.8(38.5-71.0)$ & $60.2(56.2-64.1)$ & 0.492 \\
\hline Diabetes & $16.7(6.97-31.36)$ & $16.5(13.46-19.50)$ & n.s. \\
\hline Depression & $69.2(48.2-85.7)$ & $28.1(24.3-32.0)$ & $<0.001$ \\
\hline Hypertension & $56.4(39.6-72)$ & $45.9(41.9-49.9)$ & n.s. \\
\hline
\end{tabular}

Values are means \pm SD with $95 \%$ CI in parentheses or percentages with $95 \% \mathrm{CI}$ in parentheses, unless indicated otherwise. ${ }^{\text {a }}$ MannWhitney test. ${ }^{\mathrm{b}}$ t test.

Table 3. Adipokine concentrations by BMI categories and waist circumferenc

\begin{tabular}{lccc}
\hline & Leptin, $\mathrm{ng} / \mathrm{ml}$ & sOB-R, $\mathrm{ng} / \mathrm{ml}$ & FLI \\
\hline BMI & & & \\
$\quad<20(\mathrm{n}=10)$ & $5.79 \pm 6.99(0.5-10.7)$ & $51.35 \pm 23.31(32.15-62.0)$ & $0.10 \pm 0.12(0.02-0.17)$ \\
$\quad 20-24.9(\mathrm{n}=117)$ & $11.97 \pm 8.77(5.6-15.1)$ & $34.20 \pm 23.26(18.8-41.3)$ & $0.48 \pm 0.54(0.16-0.55)$ \\
$\quad 25-29.9(\mathrm{n}=309)$ & $20.77 \pm 13.79(10.0-31.0)$ & $35.06 \pm 22.21(19.9-45.5)$ & $0.77 \pm 0.68(0.29-1.04)$ \\
$\quad \geq 30(\mathrm{n}=229)$ & $30.66 \pm 16.8(16.2-41.9)$ & $32.5 \pm 18.99(19.5-40.6)$ & $1.22 \pm 1.06(0.55-1.55)$ \\
Waist circumference & & & \\
$\quad \leq 88 / 102$ cm $(\mathrm{n}=267)$ & $13.53 \pm 11.18^{\mathrm{a}}$ & $33.98 \pm 21.97$ & $0.53 \pm 0.55^{\mathrm{a}}$ \\
$\quad>88 / 102 \mathrm{~cm}(\mathrm{n}=397)$ & $28.42 \pm 15.50^{\mathrm{a}}$ & $34.55 \pm 21.13$ & $1.10 \pm 0.95^{\mathrm{a}}$ \\
\hline
\end{tabular}

Figures are means \pm SD with 95\% CI in parentheses. Kruskal-Wallis test across BMI. Leptin: $\mathrm{p}=0.00010$. FLI: $\mathrm{p}=0.00010$. ${ }^{\text {a }}$ Comparison between waist circumference $\leq 88 / 102 \mathrm{~cm}$ and $>88 / 102 \mathrm{~cm}, \mathrm{p}<0.05$.

normal or underweight subjects and across categories of BMI. No differences in sOB-R were observed but FLI was higher in people with a large waist circumference $(1.10 \pm 0.95)$ compared to those with a smaller waist circumference $(0.53 \pm 0.55)$.

Cox hazard proportional models (table 4) adjusted for sex, age and education showed that the relative risk of having dementia increased, the higher the log sOB-R (hazard ratio $=3.38$; 95\% CI 1.72-7.45). Neither obesity, measured by BMI or waist circumference, hypertension nor diabetes were related to greater odds of dementia; however, depression at baseline remained a significant risk factor (hazard ratio $=4.33$; 95\% CI 1.94-7.49) for dementia. 
Albala et al.: Low Leptin Availability as a Risk Factor for Dementia in Chilean Older People

Table 4. Cox hazard regression models for dementia according to leptin and sOB-R at baseline

\begin{tabular}{|c|c|c|c|c|c|c|c|c|c|c|c|c|}
\hline \multirow[t]{2}{*}{ Dementia } & \multicolumn{3}{|c|}{ Model 1} & \multicolumn{3}{|c|}{ Model 2} & \multicolumn{3}{|c|}{ Model 3} & \multicolumn{3}{|c|}{ Model 4} \\
\hline & HR & $95 \% \mathrm{CI}$ & $\mathrm{p}$ & HR & $95 \% \mathrm{CI}$ & $\mathrm{p}$ & HR & $95 \% \mathrm{CI}$ & $\mathrm{p}$ & HR & $95 \% \mathrm{CI}$ & $\mathrm{p}$ \\
\hline log leptin & 1.26 & $0.88-1.82$ & 0.213 & 1.41 & $1.82-3.44$ & 0.207 & 1.35 & $0.84-2.57$ & 0.176 & 1.52 & $0.80-2.90$ & 0.202 \\
\hline $\log \mathrm{sOB}-\mathrm{R}$ & 2.55 & $1.43-4.52$ & 0.001 & 2.70 & $1.49-4.90$ & 0.001 & 3.19 & $1.46-4.81$ & 0.001 & 3.58 & $1.72-7.45$ & 0.001 \\
\hline Age (years) & 1.15 & $1.07-1.22$ & $<0.001$ & 1.13 & $1.06-1.21$ & 0.001 & 1.13 & $1.06-1.21$ & $<0.001$ & 1.06 & $0.96-1.17$ & 0.224 \\
\hline Women & 0.30 & $0.15-0.63$ & 0.001 & 0.28 & $0.13-0.62$ & 0.001 & 0.29 & $0.13-0.65$ & 0.002 & 0.21 & $0.08-0.57$ & 0.002 \\
\hline$\geq 8$ years of education ${ }^{a}$ & 0.33 & $0.15-0.74$ & 0.007 & 0.33 & $0.14-0.79$ & 0.013 & 0.29 & $0.14-0.79$ & 0.013 & 0.50 & $0.19-1.29$ & 0.151 \\
\hline Obesity & & & & 1.08 & $0.54-2.14$ & 0.836 & 1.23 & $0.55-2.78$ & 0.618 & 1.34 & $0.52-3.47$ & 0.548 \\
\hline Waist circumference ${ }^{b}$ & & & & & & & 0.77 & $0.34-1.72$ & 0.522 & 0.86 & $0.30-2.43$ & 0.771 \\
\hline Depression & & & & & & & & & & 4.33 & $1.94-9.7$ & $<0.001$ \\
\hline Hypertension & & & & & & & & & & 0.60 & $0.29-1.22$ & 0.155 \\
\hline Diabetes & & & & & & & & & & 1.32 & $0.49-3.56$ & 0.579 \\
\hline
\end{tabular}

HR = Hazard ratio. Reference categories: ${ }^{\mathrm{a}}<8$ years education; ${ }^{\mathrm{b}}$ men $>102 \mathrm{~cm}$, women $>88 \mathrm{~cm}$.

\section{Discussion}

In this cohort study of community-living people aged 60 years and older in Santiago de Chile, we found that low leptin availability - represented by a high sOB-R and a high FLI - is a risk factor for dementia. sOB-R, the stronger binding activity of leptin, has been shown to modulate plasma leptin [28] regulating the bioavailability of free leptin.

The neuroprotective action of leptin has been demonstrated in animal models and has been ascribed to leptin's role in neuroprotection and neurogenesis in the hippocampus [29]. On the other hand, a disorder in leptin signaling at the hippocampus has been observed in AD patients by the same authors. The 8 years of follow-up of the Framingham cohort have shown that leptin is inversely related to AD and directly associated with markers of brain health [30].

Paradoxically, a number of epidemiologic studies have shown that obesity, characterized by high levels of circulating levels of leptin [31], increases the risk of dementia and is associated with damage of the brain structure and a decrease in the brain volume [30]. In the Baltimore longitudinal study of aging [32], the authors have shown that a high BMI is associated with a faster decline in memory and executive function over time. However, longitudinal studies are not conclusive. A study carried out in men in Australia looking for an association with incident AD [33] did not find an association. Insights for these apparent contradictory results are highlighted by the study of the trajectories of dementia by BMI over time in the cardiovascular health study [5] where midlife obesity was associated with higher dementia risk but BMI after 65 years was inversely related with incident dementia. Concordant results were obtained in a twin study [34] conducted in Sweden among 8,534 twins aged 65 years and older, where overweight and obesity at midlife independently increased the risk of AD and vascular dementia. Similar results were observed in a 27-year follow-up study conducted among 10,276 people registered in a health care delivery organization from California [6], where obesity in midlife increased the risk of dementia independently of comorbid conditions.

We did not find an association between dementia and obesity measured by BMI or waist circumference. The Sacramento Area Latino Study on Aging (SALSA) [35] found a lower risk of cognitive impairment in relation to high levels of leptin at the 10-year follow-up only in people with no abdominal obesity but not in subjects with a large waist circumference (men $>40$ in; women >35 in). However, our results are concordant with the higher availability of free leptin in people without dementia in both obese and nonobese subjects. The higher FLI and lower leptin sOB-R concentrations in obese people than in normal or underweight subjects mean that in this cohort the obese were not leptin resistant. Moreover, in the same cohorts, obese participants have higher survival and lower disability than normal and underweight subjects $[36,37]$. 
On the other hand, among the incident cases of dementia, we found a significantly higher proportion of low weight at baseline compared to subjects who did not develop dementia. This finding is similar to what has been found in some studies showing a weight decrease preceding the appearance of $\mathrm{AD}$ [6] and in people with incipient $\mathrm{AD}$ [38], suggesting that the weight decrease is another sign of early brain dysfunction. A limitation of our study is that the diagnosis of dementia was done with a screening test [26]; therefore, it is possible that some people with incipient dementia were not detected at baseline. However, the screening test has proved to have high sensitivity and specificity and is used in many Latin American countries for population studies [22].

Another limitation is that we do not have obesity data at midlife; therefore, we are unable to determine if earlier obesity is a risk factor for dementia. The longitudinal design and the length of the follow-up (15 years) are the principal strengths of the study.

The relationship between obesity and dementia is complex, considering that both obesity and aging are associated with pathophysiological changes through which brain damage can be caused. Although we did not find an association between obesity and dementia, other studies in younger cohorts are needed to assess the effect of demographic origin on that association. The huge lifestyle changes of the Latin American population that have occurred in the past three decades [39], with a high prevalence of obesity and sedentary behavior in all age groups [40], should have important implications for the future health of an aging society with an increasing burden of dementia, in which the prevalence of obesity and overweight reaches almost half of the population.

Although it was not the focus of the current research, this study confirms the importance of depression in older people. The fourfold adjusted risk of dementia in people with depression at baseline compared with people not having depression highlights the importance to detect and treat depression in older people.

\section{Acknowledgement}

Research related to this article was funded by the Chilean National Fund for Science and Technology (Fondecyt) grant 1130947.

\section{Disclosure Statement}

The authors declare that they have no conflicts of interest.

\section{References}

1 Nitrini R, Bottino CMC, Albala C, Custodio Capuñay NS, Ketzoian C, Llibre Rodriguez JJ, et al: Prevalence of dementia in Latin America: a collaborative study of population-based cohorts. Int Psychogeriatr 2009;21:622630.

2 Kalaria RN, Maestre GE, Arizaga R, Friedland RP, Galasko D, Hall K, et al: Alzheimer's disease and vascular dementia in developing countries: prevalence, management, and risk factors. Lancet Neurol 2008;7:812-826.

3 Albala C, Lebrão ML, León Díaz EM, Ham-Chande R, Hennis AJ, Palloni A, et al: Encuesta Salud, Bienestar y Envejecimiento (SABE): metodología de la encuesta y perfil de la población estudiada. Rev Panam Salud Pública 2005;17:307-322.

4 Fuentes P, Albala C: An update on aging and dementia in Chile. Dement Neuropsychol 2014;8:2-5.

5 Fitzpatrick AL: Midlife and late-life obesity and the risk of dementia. Arch Neurol 2009;66:336-342.

6 Whitmer RA, Gunderson EP, Barrett-Connor E, Quesenberry CP, Yaffe K: Obesity in middle age and future risk of dementia: a 27 year longitudinal population based study. BMJ 2005;330:1360.

7 Morrison CD: Leptin signaling in brain: a link between nutrition and cognition? Biochim Biophys Acta 2009; 1792:401-408. 
8 Bouret SG, Draper SJ, Simerly RB: Trophic action of leptin on hypothalamic neurons that regulate feeding Science 2004;304:108-110.

9 Greco SJ, Bryan KJ, Sarkar S, et al: Leptin reduces pathology and improves memory in transgenic mouse model of Alzheimer Disease. J Alzheimers Dis 2010;19:1155-1167.

10 Fewlass DC, Noboa K, Pi-Sunyer FX, Johnston JM, Yan SD, Tezapsidis N: Obesity-related leptin regulates Alzheimer's Abeta. FASEB J 2004;18:1870-1878.

11 Luchsinger JA, Mayeux R: Adiposity and Alzheimer's disease. Curr Alzheimer Res 2007;4:127-134.

12 Scarpace PJ, Matheny M, Shek EW: Impaired leptin signal transduction with age-related obesity. Neuropharmacology 2000;39:1872-1879.

13 Myers MG, Heymsfield SB, Haft C, Kahn BB, Laughlin M, Leibel RL, et al: Challenges and opportunities of defining clinical leptin resistance. Cell Metab 2012;15:150-156.

14 Myers MG Jr, Leibel RL, Seeley RJ, Schwartz MW: Obesity and leptin resistance: distinguishing cause from effect. Trends Endocrinol Metab 2010;21:643-651.

15 Tartaglia LA, Dembski M, Weng X, Deng N, Culpepper J, Devos R, et al: Identification and expression cloning of a leptin receptor, OB-R. Cell 1995;83:1263-1271.

16 Tartaglia LA: The leptin receptor. J Biol Chem 1997;272:6093-6096.

17 Lee EB: Obesity, leptin, and Alzheimer's disease. Ann NY Acad Sci 2011;1243:15-29.

18 Lammert A, Kiess W, Bottner A, Glasow A, Kratzsch J: Soluble leptin receptor represents the main leptin binding activity in human blood. Biochem Biophys Res Commun 2001;283:982-988.

19 Schaab M, Kausch H, Klammt J, Nowicki M, Anderegg U, Gebhardt R, et al: Novel regulatory mechanisms for generation of the soluble leptin receptor: implications for leptin action. PLoS One 2012;7:e34787.

20 Sun Q, Dam RM Van, Meigs JB, Franco OH, Mantzoros CS, Hu FB: Leptin and soluble leptin receptor levels in plasma and risk of type 2 diabetes in US women: a prospective study. Diabetes 2010;59:611-618.

21 Fernández-Galaz C, Fernández-Agulló T, Campoy F, Arribas C, Gallardo N, Andrés A, et al: Decreased leptin uptake in hypothalamic nuclei with ageing in Wistar rats. J Endocrinol 2001;171:23-32.

22 Albala C, Lebrão ML, León Díaz EM, Ham-Chande R, Hennis AJ, Palloni A, et al: Encuesta Salud, Bienestar y Envejecimiento (SABE): metodología de la encuesta y perfil de la población estudiada. Rev Panam Salud Pública 2005;17:307-322.

23 Albala C, Sánchez H, Lera L, Angel B, Cea X: Socioeconomic inequalities in active life expectancy and disability related to obesity among older people. Rev Med Chil 2011;139:1276-1285.

24 Folstein MF, Folstein SE, McHugh PR: Mini-mental state: a practical method for grading the cognitive state of patients for the clinician. J Psychiatr Res 1975;12:189-198.

25 Pfeffer RI, Kurosaki TT, Harrah CH Jr, Chance JM, Filos S: Measurement of functional activities in older adults in the community. J Gerontol 1982;37:323-329.

26 Quiroga LP, Albala BC, Klaasen PG: Validación de un test de tamizaje para el diagnóstico de demencia asociada a edad, en Chile. Rev Med Chil 2004;132:467-478.

27 Sheikh RL, Yesavage JA: Geriatric Depression Scale (GDS). Recent evidence and development of a shorter version. Clin Gerontol 1986;5:165-173.

28 Huang L, Wang Z, Li C: Modulation of circulating leptin levels by its soluble receptor. J Biol Chem 2001;276: 6343-6349.

29 Bonda DJ, Stone JG, Torres SL, Siedlak SL, Perry G, Kryscio R, et al: Dysregulation of leptin signaling in Alzheimer disease: evidence for neuronal leptin resistance. J Neurochem 2014;128:162-172.

30 Lieb W, Beiser AS, Vasan RS, Zaldy S, Au R, Harris TB, et al: Association of plasma leptin with incident Alzheimer disease and MRI measures of brain aging: the Framingham Study. JAMA 2010;302:2565-2572.

31 Considine RV, Sinha MK, Heiman ML, Kriauciunas A, Stephens TW, Nyce MR, et al: Serum immunoreactiveleptin concentrations in normal-weight and obese humans. N Engl J Med 1996;334:292-295.

32 Gunstad J, Lhotsky A, Wendell CR, Ferrucci L, Zonderman AB: Longitudinal examination of obesity and cognitive function: results from the Baltimore longitudinal study of aging. Neuroepidemiology 2010;34:222-229.

33 Power BD, Alfonso H, Flicker L, Hankey GJ, Yeap BB, Almeida OP: Body adiposity in later life and the incidence of dementia: the health in men study. PLoS One 2011;6:e17902.

34 Xu WL, Atti AR, Gatz M, Pedersen NL, Johansson B, Fratiglioni L: Midlife overweight and obesity increase latelife dementia risk: a population-based twin study. Neurology 2011;76:1568-1574.

35 Zeki Al Hazzouri A, Haan MN, Whitmer RA, Yaffe K, Neuhaus J: Central obesity, leptin and cognitive decline: the Sacramento Area Latino Study on Aging. Dement Geriatr Cogn Disord 2012;33:400-409.

36 Arroyo P, Lera L, Sánchez H, Bunout D, Luis J, Albala C: Composición corporal y limitaciones funcionales en ancianos. Rev Med Chil 2007;135:846-854.

37 Albala C, Sánchez H, Lera L, Arroyo P: Anthropometry, mortality and functional limitations in Chilean elders. Gerontologist 2007;47:412.

38 Gillette Guyonnet S, Abellan Van Kan G, Alix E, Andrieu S, Belmin J, Berrut G, Bonnefoy M, Brocker P, Constans T, Ferry M, Ghisolfi-Marque A, Girard L, Gonthier R, Guerin O, Hervy MP, Jouanny P, Laurain MC, Lechowski L, Nourhashemi F, Raynaud-Simon A, Ritz P, et al; International Academy on Nutrition and Aging Expert Group: IANA (International Academy on Nutrition and Aging) Expert Group: weight loss and Alzheimer's disease. J Nutr Heal Aging 2007;11:38-48.

39 Albala C, Vio F, Kain J, Uauy R: Nutrition transition in Chile: determinants and consequences. Public Health Nutr 2002;5:123-128.

40 Vio F, Albala C, Kain J: Nutrition transition in Chile revisited: mid-term evaluation of obesity goals for the period 2000-2010. Public Health Nutr 2008;11:405-412. 